\title{
Role of early childhood educators professionalism in managing learning activities in RA Uniq Kota Pekanbaru
}

\author{
Raihana, Dian Tri Utami, Ary Antony Putra \\ Universitas Islam Riau, Indonesia \\ E-mail: raihana@fis.uir.ac.id
}

\section{Article History \\ Submitted: June 23, 2020 \\ Accepted: December 12, 2020 \\ Published: January 5, 2021 \\ DOI:10.26555/jecce.v3i2.2940}

\begin{abstract}
Learning management process in early childhood classroom is inseparable from the early childhood educators' professional role in creating a learning atmosphere, managing learning process, implementing learning strategies, providing learning media and learning model that are able to create a conducive, safe, and comfortable learning atmosphere. Good curriculum and learning management plan are likely to fail to meet their goals when teachers could not perform their professional role well. In RA Uniq, teachers' professional role is pivotal in supporting the learning plan and management. The present study aimed to explore the role of early childhood educators' professionalism in managing the learning process in RA Uniq To this end, five participants were recruited, consisting of four teachers as the main informant and the head of RA uniq as additional informant. The present study applied qualitative method, the data were collected using interview, observation, and documentation. This study revealed that early childhood educators in RA Uniq played some professional role in managing the learning process, namely as facilitator, motivator, inspirator, model, and a caregiver.

Keywords: Role, Professionalism, Early Childhood Educators
\end{abstract}

\section{Abstrak}

Proses pengelolaan pembelajaran di kelas anak usia dini tidak terlepas dari bagaimana peran profesional pendidik PAUD dalam hal ini guru menciptakan suasana belajar, mengelola pembelajaran, strategi pembelajaran, media pembelajaran, model pembelajaran yang digunakan dan menciptakan suasana pembelajaran yang kondusif, sehingga membuat siswa merasa nyaman dan aman. Sebagus apapun kurikulum dan rencana pengelolaan dalam pembelajaran tetapi tidak didukung dengan peran profesionalisme pendidik PAUD maka kurikulum dan rencana pengelolaan pembelajaran tersebut tidak akan tersampaikan dengan baik. Begitu juga yang terjadi di RA Uniq, peran profesionalisme guru sangat diperlukan untuk menunjang keberhasilan pengelolaan dan rencana pembelajaran. Tujuan dilaksanakan penelitian ini adalah untuk mengetahui bagaimana peran profesionalisme pendidik PAUD dalam mengelola pembelajaran di RA Uniq. Subjek dalam penelitian ini berjumlah 5 orang, terdiri dari 4 orang guru sebagai informan utama dan 1 orang Kepala Sekolah RA Uniq sebagai informan tambahan. Metode yang digunakan dalam penelitian ini adalah kualitatif, sementara itu data dikumpulkan menggunakan wawancara, observasi dan dokumentasi. Adapun hasil penelitian ini menemukan bahwa pendidik PAUD di RA Uniq memiliki peran profesionalisme dalam mengelola pembelajaran adalah sebagai fasilitator, motivator, pemberi inspirasi, model bagi anak didik dan sebagai pengasuh.

Kata Kunci : Peran, Profesionalisme, Pendidik PAUD 


\section{INTRODUCTION}

Education is fundamental for human life, started from early-childhood education To higher education levels. Early-childhood education has been proven to significantly contribute to the growth and development of human life. In childhood period, children begin to capture a range of information from their surroundings. Their cells grow along with experience, thus making it is necessary to provide a stimulus and facilitate children's development in order to support optimal growth (Masnipal, 2013).

Benjamin S. Bloom's neuroscientific study revealed that brain cell development in 0-4 years old children reaches $50 \%$ and reaches $80 \%$ when they are 8 years old (Priyanto, 2014). Accordingly, it is important to stimulate children's intelligence by providing their needs, including health, brain-stimulating activities, nutritious foods, and proper education. Based on Children Developmental Attainment Standard stipulated in Regulation of Minister of Education and Culture of the Republic of Indonesia no. 137 of 2014, six aspects of children's development may stimulate their intelligence, namely: (1) religious and moral values, (2) physical-motor factors, (3) cognitive factors, (4) linguistic factors, (5) Socio-emotional factors, and (6) art (Wulandari \& Purwanta, 2020).

Hence, to assist children's developmental progress in education, it is necessary to have early childhood educators who are capable of managing learning activities in the classroom, creating a supportive learning atmosphere, possessing a range of learning strategies, providing active learning media, and being creative to make children feel comfortable and safe during learning activities. Article 4 of Law no. 14 of 2005 states that teacher, as professional, functions to improve the role and dignity of a teacher as a learning agent. During an online early childhood education workshop conducted in Central Java in 2015, it was stated that children's learning process is affected by the early childhood educator's roles, which consist of: (1) facilitator, (2) motivator, (3) behavioral model, (4) observer, (5) facilitator, and (6) caregiver.

One of the factors that influences children's successful learning activities is the optimal role of professional teacher in learning management, considering that great curriculum and learning management plan will not work if the teachers lack of professionalism. However, the fact shows that many teachers still failed to implement the professionalism stipulated by Law no. 14 of 2005. Argues that many teachers are not aware of their role as an educator, meaning that they see their role merely as a job that must be done to fulfill their needs. Instead of devoting themselves to be a professional teachers, they are occupied by their personal needs to survive (Noor, 2020).

\begin{tabular}{|l|c|l|}
\hline & Page & \\
\hline & 89 & \\
\hline
\end{tabular}


Early childhood education, as stipulated in Law of Education system, is divided into three systems, namely formal, nonformal, and informal. The formal system is carried out through Taman Kanak-Kanak (TK) and Raudhatul Athfal (RA), also including Bustanul Athfal (equal to kindergarten) for children aged from 4-6 years old. With regard to nonformal education, it is carried out by preschool playgroup for children aged 2-4 years, while the nonformal education is carried out through childcare for children aged from 3 months to 2 years old

RA Uniq is an education institution located in Jalan Kartama Komplek Kartama Raya Blok. H. 35, RT.02 RW.03, Kelurahan Perhentian1Marpoyan, Kecamatan Marpoyan1Damai Kota Pekanbaru. Established on 27 January 2013, this institution employs seven early childhood educators and one administrative staff. Out of seven educators, only two of them held bachelor's degrees, three of them were pursuing their bachelor's degree, and the rest was graduated from senior high school. Their building was only a rented house. The number of parents who register their children in RA Uniq increases every year, in the last two years, RA Uniq had to carry out screening due to limited teachers and classroom available. Such a condition drew our interest to explore their professionalism in learning management, which makes the parents entrusted their children's education in this institution.

\section{METHOD}

A qualitative method was applied in order to gain an in-depth understanding of the educators' professional role in RA Uniq. The data were collected through interviews and documentation. Five participants were recruited, consisting of four educators (as the primary informant) and the head of RA Uniq (as the secondary informant). Due to the pandemic situation, classroom observation could not be done since the learning activities were not conducted offline. The present study was conducted in two months, from July to August 2020. The interview was open-ended, which was aimed at obtaining the research purpose through a conversation (Moleong, 2018). The interview was conducted twice, it was done in order to obtain adequate information to obtain the research goal.

The documentation was carried out particularly to the teachers' role during the management process and students' learning outcome. It included the photograph of the school's building, classrooms, structural documents, history of RA Uniq, the teachers' and students' condition, and other learning-related documents.

\begin{tabular}{|l|c|c|}
\hline & Page & \\
\hline & 90 & \\
\hline
\end{tabular}




\section{RESULT AND DISCUSSION}

Teachers, as an educator, are demanded to be professional in managing the learning activities. They play a pivotal role in students' learning process, let alone that of early childhood education. Preschool children are unique, they require optimal stimulation to support their growth and development (Roza et al., 2020).

The findings of the study, based on four primary informants, are described below.

First, teachers as a facilitator. Based on the interview, two teachers, i.e., SV and WL, stated that some parents asked teachers to help them giving advice to their children to obey their parents at home. Such a phenomenon showed the parents' dependency on the teachers when their children showed disobedience. As revealed during an interview with SV: "Some parents even asked us to advise their children because they were annoyed by their children, they said that children listen more to us than to their own parents."

Second, teachers as motivator. Teachers in RA Uniq were always involved in encouraging children's participation in every activity, as shown by a field note with RN: "Children are unique as a result of parenting, sometimes we encourage them through motivational story or modeling."

Third, teacher as an Inspirator. Teachers in RA Uniq always encourage low-motivated students. As asserted by RN and YL during the interview: "While some children do need stimulus, sometimes we show them what we are going to make in a meeting, or give them an idea about what to do, other children can directly understand our instruction and example."

Fourth, teacher as a model for students. Teachers in RA Uniq have been aware of their role as a model for their students, making them thoughtfully consider their speech and behavior. As YL stated: "... It is a must. They, preschool children, tend to listen and imitate anything their teachers do." Similarly, WL also asserted that: "Over time, every teacher here realizes that we have to be a good model for children because children see, children do."

Fifth, teacher as a Caregiver RA Uniq provided a Playgroup and Class-A for 3-4 years old children, meaning that teachers who held both classes played a dual role as a teacher and a caregiver. This role was shown by our fieldnote with SV who handled the playgroup, she stated that: "In PG, we acted as both teacher and caregiver since they are still in physical and motor developmental process, different from those in B2 and B3 classes. Some of them even had not

\begin{tabular}{|l|c|c|}
\hline & Page & \\
\hline & 91 & \\
\hline
\end{tabular}


been able to speak clearly. However, it is where the challenge is, I have to be really patient and learn about how to treat 3-years old children's behavior."

Teachers' professionalism is pivotal in learning management process. Accordingly, an ECE institution should possess professional educators as defined by Law no. 20 of 2003, which states that ECE teacher refers to a professional whose duty are to plan, implement, and assess the learning process, as well as carry out guidance, caregiving, and protection for students (Direktorat PAUD, 2011). Professionalism highlights the mastery of knowledge and skills, as well as attitudes and behaviors of a teacher during a learning process (Musa, 2016).

Professionalism is important since it determines the students' learning success. A professional teacher is capable of understanding and stimulating their students' developmental aspects and characteristics. Based on the findings of the study, it was revealed that teachers in RA Uniq, in carrying out the early childhood learning process, performed five professional roles, namely:

\section{Role as a Facilitator}

Teachers, as a facilitator, should facilitate the learning process of their students. Such facilitation could be in the form of a safe and comfortable environment, a clean, well-ventilated classroom with adequate lighting, a good table and chairs, and provision of facilitation when parents and children face communication difficulties (Zakiya \& Nurhafizah, 2019).

Teachers are parents' representatives at school, meaning that they take the parents' teaching role. Teachers in RA Uniq served as a facilitator between parents and their children at school. Some parents asked teachers to help them giving advice to the children when they felt they were failed to do so. As a facilitator, teachers should treat their students well. They are also required to understand their students through a range of learning activities. In addition, they are also demanded to be competent in addressing differences and problems that stem from the students themselves. The primary duty of a teacher, during a learning process, is stimulating the students' curiosity, interest, and learning motivation (Mulyasa, 2013).

As a facilitator, teachers are also demanded to provide a satisfactory service for their students in learning process (Esi, et al., 2016). Such service could be in the form of, among others, provision of stimulation during the learning process and time for children to consult and tell about their difficulties. Teachers should be able to see their children as a responsible individual who and are able to organize learning resources to make the students involve in a learning activity based on correct instruction (Naibaho, 2018).

\begin{tabular}{|l|c|l|}
\hline & Page & \\
\hline & 92 & \\
\hline
\end{tabular}


Some statements above explain that role of facilitator aims to ease the students during learning processes, either in the form of facilities, infrastructure, or even teachers' understanding of students. These may prevent students from experiencing stressful, intimidating learning activities.

\section{Role as A Motivator}

In RA Uniq, teachers also exhibited a role as a motivator, where they encouraged and support their students to participate in every playing and learning activity. Proper motivation may lead to optimal learning outcomes (Esi et al., 2016). Teachers in RA Uniq often encouraged their students through motivational stories. Telling motivational stories is expected to provide the students with models that make them understand behaviors that are compliant with religious and moral values that prevail in the community. Since children's world is "all-aboutplaying", teachers should involve them in playing activities to motivate them, such as roleplaying, storytelling, or giving a reward for their works and achievement.

One of the teachers' duties is to motivate their students (Sardiman, 2016). Motivation serves as one of the factors that enhances learning quality, given that only highly-motivated students can learn optimally (Mulyasa, 2013). It is in line with (Esi et al., 2016) study, which shows that $79.6 \%$ percent of learning outcome is affected by teachers' role as a facilitator, meaning that better motivation leads to better learning outcome.

\section{Inspirator}

Every student can view their teachers as an inspiration, considering that the teacher brings them to progress and success. In RA Uniq, teachers encourage and provide unmotivated students with new ideas during the learning process. Teachers should be able to provide good instruction for the students' progress. The instruction could be in the form of experiences of how to learn (Roseminingsih \& Lamijan, 2015). Teachers who act as an inspirator are demanded to have a wide insight, good communication skill, be a hard worker, flexible, and have a strong principle (Fatah, 2011). Encouraging children to participate in the learning process could not be done only by giving motivation, it is necessary to give them inspiration when they run out of ideas and creativity.

\section{Model for students}

What children do is a result of their adaptation to the surroundings. Children may acquire various lessons when they observe and imitate their environment. From observing and imitating their environment, they can distinguish bad things from good ones. Accordingly, teachers should act as a model in order to form children's behaviors. Preschool-aged children

\begin{tabular}{|l|c|l|}
\hline & Page & \\
\hline & 93 & \\
\hline
\end{tabular}


need a model they can directly observe and imitate, in this regard, parents and teachers are the closest people a child can observe and imitate (Hidayat, 2014).

Teachers in RA uniq have been aware of their role as a model for their students, making them thoughtfully consider their speech and behavior. Teachers in RA Uniq were also obliged to wear long dress and hijab to teach the children Islamic values related to Islamic women's clothing, in addition to talking to students politely. Teachers in RA Uniq were aware that teachers' negative attitudes may affect children's positive energy and optimism, thus making them exhibit positive and optimistic attitude toward the children despite problems they face. Teachers serve as a model for students, making their roles are essentials in the learning process (Ratnawati, 2018).

In the learning process, children do not only see their teachers' knowledge but also their attitude, behavior, and thinking processes (Setyowati \& Nurdahlia, 2018). Teachers' personalities during the learning process significantly affect the students' personalities. Accordingly, teachers are expected to be able to serve as a good model for students.

\section{Caregiver}

Caregiving activities in school require compassion through warm touches, hug, smiles, and eye contact, which significantly influences a child's physical and psychological development and growth (Rahmiyah et al., 2016).

Teachers' role as a caregiver could not be found in all education level. However, Early childhood education provides care and services for children until they are at the age of six (Roza et al. 2020). RA Uniq provided a Playgroup and Class-A for 3-4 years old children, meaning that teachers who held both classes played dual role as a teacher and a caregiver. This was shown by our fieldnote with SV who was responsible for handling the playgroup, stating that dual role, particularly in PG and Class-A, is inevitable. This occurs because preschool-aged children have not been able to be independent, they are still in a learning phase. With this regard, teachers play a pivotal role in creating a safe, comfortable environment for children. Teachers are required to show compassion and sincerity in teaching preschool-aged children.

\section{CONCLUSION}

An early childhood educator is considered professional when he or she manages to perform his or her tasks, despite personal or professional challenges he or she faces. Professionalism is important since it determines the students' learning success. A professional teacher is capable of understanding and stimulating their students' developmental aspects and characteristics.

\begin{tabular}{|l|c|l|}
\hline & Page & \\
\hline & 94 & \\
\hline
\end{tabular}


Teachers in RA uniq are aware of the importance of teachers professionalism in learning management, thus making them did their best to carry out their professional role.

Due to qualitative approach used in this study, the obtained data could not represent overall ECE teachers in Indonesia. Accordingly, future studies are recommended to employ quantitative method in order to obtain more generalizable data. Future studies can use this study as a basis when they aim to explore the same variable from different perspectives.

\section{REFERENCES}

Direktorat PAUD. (2011). Peraturan Menteri Pendidikan Nasional Tentang Standar Pendidikan Anak Usia Dini. Jakarta: Kemendiknas.

Esi, Purwaningsih, E., \& Okianna. (2016). Peranan guru sebagai fasilitator dan motivator dalam meningkatkan hasil belajar di kelas XI SMK. Jurnal Pendidikan Dan Pembelajaran, 5(10), $1-14$.

Fattah, Nanang. (2011). Landasan Manajemen Pendidikan. Bandung: PT. Remaja Rosdakarya.

Hidayat, Otib Sabiti. (2014). Metode Pengembangan Moral \& Nilai-Nilai Agama. Tangerang Selatan: Universitas Terbuka.

Jateng, P. (2015). Inilah Peran Guru PAUD Dalam Pendidikan Anak Usia Dini. PAUD.Id. https://www.paud.id/peran-guru-paud-dalam-pendidikan-anak/

Masnipal, M. (2013). Siap Menjadi Guru dan Pengelola PAUD Profesional (1st ed.). PT Elex Media Komputindo.

Moleong, L. J. (2018). Metodologi penelitian kualitatif (38th ed.). PT Remaja Rosdakarya.

Mulyasa.E. (2013). Standar Kompetensi dan Sertifkasi Guru. Bandung: PT. Remaja Rosdakarya.

Musa, M. I. (2016). Pengembangan Kompetensi Guru Terhadap Pelaksanaan Tugas Dalam Mewujudkan Tenaga Guru Yang Profesional. Jurnal Pesona Dasar, 2(4), 8-27.

Naibaho, D. (2018). Peranan Guru Sebagai Fasilitator Dalam Perkembangan Peserta Didik. Jurnal Christian Humaiora, 2(1), 77-86. https://doi.org/10.46965/jch.v2i1.112

Noor, G. M. (2020). Hilangnya Profesionalisme Guru, Salah Siapa? Bengkulu News. https://www.bengkulunews.co.id/hilangnya-profesionalisme-guru-salah-siapa/

Priyanto, A. (2014). Pengembangan Kreativitas Pada Anak Usia Dini Melalui Aktivitas Bermain. Jurnal IImiah Guru Caraka Olah Pikir Edukatif, (2), 41-47.

Rahmiyah, R., Budiastutik, I., \& Sutrisno, S. (2016). Hubungan Peran Guru Dan Orang Tua Dalam Pelaksanaan Pola Konsumsi Dengan Status Gizi Anak Usia Dini Di Raudhatul

\begin{tabular}{|l|c|l|}
\hline & Page & \\
\hline & 95 & \\
\cline { 3 - 4 } & & \\
\hline
\end{tabular}


Atfal Jamiatul Khair Pontianak. Jurnal Edukasi. Pontianak: Universitas Muhammadiyah., 4(2), 129-135. https://doi.org/10.1145/3132847.3132886

Ratnawati. (2018). Peran Guru Sebagai Model Dalam Pembentukan Karakter Peserta Didik. Prosiding Seminar Nasional Pendidikan. STKIP Andi Manopo Pangkep.

Rusman, R. (2014). Model-Model Pembelajaran: Mengembangkan Profesionalisme Guru (2nd ed.). Raja Grafindo Persada.

Roseminingsih \& Lamijan Hadi Susarno. (2015). Teori dan Praktik Pendidikan. Surabaya: Lembaga Pengkajian dan Pengembangan IImu Pendidikan Fakultas IImu Pendidikan Universitas Susrabaya.

Roza, D., Nurhafizah, N., \& Yaswinda, Y. (2020). Urgensi Profesionalisme Guru Pendidikan Anak Usia Dini dalam Penyelenggaraan Perlindungan Anak. Jurnal Obsesi : Jurnal Pendidikan Anak Usia Dini, 4(1), 277. https://doi.org/10.31004/obsesi.v4i1.325

Sardiman. (2016). Interaksi dan Motivasi Belajar-Mengajar. Jakarta: Rajawali Pers.

Setyowati, E., \& Nurdahlia, D. U. (2018). Strategi Penanganan Perilaku Menyimpang Peserta Didik Melalui Guru Sebagai Role Model. Jurnal Filsafat, Sains, Teknologi, Dan Sosial Budaya, 24(1), 35-42. https://doi.org/https://doi.org/10.33503/paradigma.v24i1.340

Suyanto dan Jihad, Asep. (2014). Menjadi Guru Profesional: Strategi meningkatkan Kualifikasi dan Kualitas Guru di Era Global. Jakarta: Esensi Erlangga Group.

Suyadi \& Ulfah, Maulidya. (2013). Konsep Dasar PUAD. Bandung: Remaja Rosdakarya.

Wulandari, H., \& Purwanta, E. (2020). Pencapaian Perkembangan Anak Usia Dini di Taman Kanak-kanak selama Pembelajaran Daring di Masa Pandemi Covid-19. Jurnal Obsesi : Jurnal Pendidikan Anak Usia Dini, 5(1), 452. https://doi.org/10.31004/obsesi.v5i1.626

Zakiya, Z., \& Nurhafizah, N. (2019). Pengembangan Keprofesian Berkelanjutan dalam Meningkatkan Profesionalisme Guru Pendidikan Anak Usia Dini. Jurnal Obsesi : Jurnal Pendidikan Anak Usia Dini, 3(2), 356. https://doi.org/10.31004/obsesi.v3i2.196

\begin{tabular}{|l|c|l|}
\hline & Page & \\
\hline & 96 & \\
\hline
\end{tabular}

